\title{
The impact of possible changes to nitrogen loss regulations on the financial viability of dairy farms in the Upper Manawatū River catchment
}

\author{
Terry G. PARMINTER ${ }^{1 *}$, Scott D. RIDSDALE ${ }^{2}$, Stefan A. BRYANT ${ }^{3}$, \\ Ian G. MCNAB ${ }^{4}$, Kate A. PROCTOR ${ }^{4}$ and Lynette A. BAISH ${ }^{4}$ \\ ${ }^{1}$ KapAg Ltd, Paraparaumu, New Zealand \\ ${ }^{2} R D$ Consulting Ltd, Palmerston North, New Zealand \\ ${ }^{3}$ BakerAg, Feilding, New Zealand \\ ${ }^{4}$ Manawatū-Wanganui Regional Council, Palmerston North, New Zealand \\ *Corresponding author: terry.parminter@kapag.nz
}

\begin{abstract}
The Manawatū-Wanganui Regional Council regional plan (the One Plan) regulates the use of natural resources in the Region and includes a table of nitrogen leaching maxima reflecting the natural capital of soils in the Region and based on Overseer ${ }^{\circledR}$ results from 2007. Dairy farms applying for controlled consents for intensive land-use activities in the Region need to comply with these maxima. However, the maxima in the Table have not been adjusted as new versions of Overseer ${ }^{\circledR}$ have been introduced since the table was produced.
\end{abstract}

This study compares the impact on representative dairy farms of complying with the original figures in the table with results from a revised table that takes into account more recent versions of Overseer ${ }^{\circledR}$. Cluster analysis was used to select five representative farms in the Tararua District and their farm systems were modified to comply with both the original and the revised table.

The current version of Overseer ${ }^{\circledR}$ was used to model the farm outputs based on the original table of leaching maxima. Compared with the baseline farm results, nitrogen losses were reduced by over $50 \%$ and milk production by $40 \%$. When the same comparison was undertaken with the table of revised maxima, the nitrogen losses were expected to reduce by almost $40 \%$ and milk production by $5 \%$. Applying the original nitrogen leaching maxima to the five representative farms resulted in about two thirds of farms within the catchment being unable to pay the interest on their debts. The revised nitrogen leaching maxima reduced this to $<10 \%$.

The nitrogen leaching maxima in the One Plan should be revised to: better reflect the changes in the

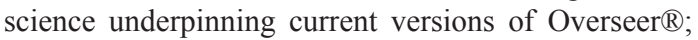
achieve the nitrogen reduction targets in the region; and minimise the impact of the One Plan policies and rules on the financial viability of existing dairy farms.

Keywords: farm systems, environmental policy, financial viability, cluster analyses

\section{Introduction}

The Manawatū-Wanganui Regional Council manages the natural resources in their region through an integrated plan (the One Plan) that combines a regional policy statement, regional plan and coastal plan. The One Plan identifies nine catchments at particular risk from contamination by intensive farming activities. Since the Plan became operative in 2014, dairy farmers within the high-risk catchments have been required to minimise their risks to the catchments and obtain land-use consents to continue with their businesses. This requirement for land-use consents also applies to intensive sheep and beef, arable and vegetable businesses. Catchment risks from nitrogen losses are minimised when farmers operate within the nitrogen leaching maxima $(\mathrm{kgN} / \mathrm{ha} / \mathrm{yr})$ contained within Table 14.2 of rule 14.1 in the One Plan.

Consent applications that describe how farms will comply with Rule 14.1 in the One Plan are usually granted a 'controlled consent' by the Regional Council. The nitrogen leaching maxima for each farm is derived from a table of cumulative nitrogen leaching maxima within specified land use capability classes (LUC) for the land that is being used for intensive farming activities (Manawatū-Wanganui Regional Council 2014, Table 14.2). Most dairy farms have land that is LUC II to IV with some VI and very little LUC I, $\mathrm{V}$ or VII. These maxima were determined in 2007 from the contribution of the different land classes to nitrogen loads in the various catchments and from using results obtained from Overseer ${ }^{\circledR}$ model version 5.2.6 (Overseer Ltd, Wellington, New Zealand) (Table 1). When applying for their land-use consent, farmers have to show how they can achieve all years in the table (i.e. from year 1 to 20 ).

In 2018, the nitrogen leaching maxima were updated by the Regional Council using Overseer ${ }^{\circledR}$ 6.2.3 (based on Hanly et al. 2018). Those figures cannot be included in the One Plan until statutory changes have been made to the Plan following the processes outlined in the Resource Management Act (RMA; New Zealand Government 1991). 


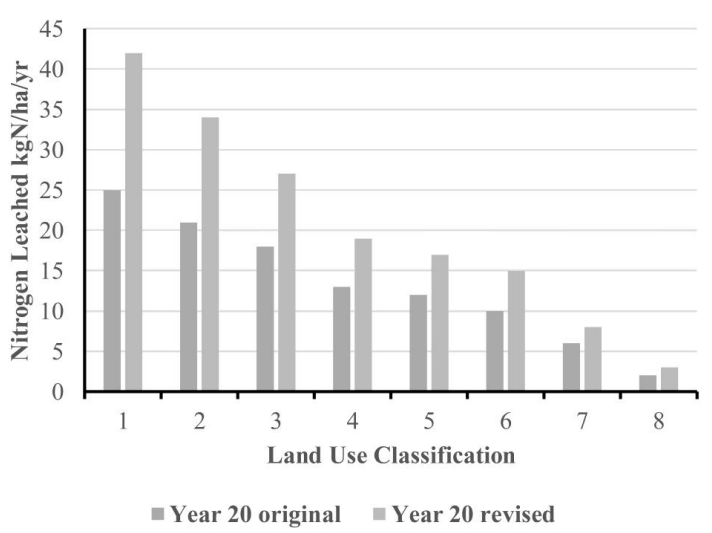

Figure 1 A comparison of year 20 in Tables 1 and 2, of the original nitrogen leaching maxima in the One Plan and a possible revision of those losses.

The updated figures from Hanly et al. (2018) are shown in Table 2 and Figure 1. All the figures in Table 2 are greater than the figures in Table 1 although Table 2 merely reflects a change in scientific calculations between 2007 and 2018. The increases are still associated with the same improvement in catchment water quality as Table 1 was calculated to achieve when it was developed in 2007. Staying with the original Table 1 would result in reductions substantially beyond the original catchment targets for nitrogen contamination and the Regional Council has no community mandate to do this.

As of 2018, farmers are not able to continue using Overseer ${ }^{\circledR}$ 5.2.6 (the 2007 version) because it is no longer supported by Overseer Ltd. Farmers presenting new intensive land-use consent applications are only able to use version 6.2 .3 or later.

The Regional Council commissioned a project in 2018 about the likely impact on dairy farmers of continuing to focus on the original nitrogen leaching maxima in Table 1 compared with updating the nitrogen leaching maxima as shown in Table 2. Dairy farmers in the Upper Manawatū River catchment were one of the last groups of farmers needing to apply for their consent. The farmers in that catchment became the focus of this study. Some of the results of the study have been previously reported in a paper describing in detail the model of on-farm dairy production that was used (Parminter et. al. 2019). The current paper describes more fully the policy context, the methodology used and the farming system implications for dairying in the Manawatū-Wanganui Region.

\section{Materials and Methods Sampling}

The data used in this analysis were obtained from base-line files in Overseer for 126 farms in the Upper Manawatū River catchment. The identity of the farm owners remained anonymous throughout the analyses. The base-line files included farm system information and nutrient budgets that had been calculated using Overseer. The project was restricted to examining the impact of possible policy changes on different farming systems and business structures rather than including farmer capability or environmental foot prints, although both of these had some influence on the data in the base-line files that were provided.

Table 1 Nitrogen leaching maxima (kgN/ha leached per year) included in Table 14.2 of the One Plan (Manawatū-Wanganui Regional Council 2014; calculated using Overseer software version 5.2.6)

\begin{tabular}{lccccccccc}
\hline $\begin{array}{l}\text { Period from the year that the rule } \\
\text { has legal effect (years) }\end{array}$ & LUC I & LUC II & LUC III & LUC IV & LUC V & LUC VI & LUC VII & LUC VIII \\
\hline 1 & 30 & 27 & 24 & 18 & 16 & 15 & 8 & 2 \\
5 & 27 & 25 & 21 & 16 & 13 & 10 & 6 & 2 \\
10 & 26 & 22 & 19 & 14 & 13 & 10 & 6 & 2 \\
20 & 25 & 21 & 18 & 13 & 12 & 10 & 6 & 2 \\
\hline
\end{tabular}

Table 2 The nitrogen leaching maxima as they would be in the One Plan if they were updated to Overseer® 6.2.3.

\begin{tabular}{lcccccccccc}
\hline $\begin{array}{l}\text { Period from the year that the rule } \\
\text { has legal effect (years) }\end{array}$ & LUC I & LUC II & LUC III & LUC IV & LUC V & LUC VI & LUC VII & LUC VIII \\
\hline 1 & 50 & 44 & 36 & 26 & 23 & 22 & 11 & 3 \\
5 & 45 & 41 & 32 & 23 & 19 & 15 & 8 & 3 \\
10 & 43 & 36 & 29 & 20 & 19 & 15 & 8 & 3 \\
20 & 42 & 34 & 27 & 19 & 17 & 15 & 8 & 3 \\
\hline
\end{tabular}




\section{Cluster analyses to select representative farms}

A hierarchical cluster analysis with dendrogram was carried out to develop representative farms for the catchment (Rokach \& Maimon 2005, pp. 321-352). The cluster analysis used twelve farm system attributes. Five of these attributes were physical attributes (farm area, the primary soil group, annual rainfall, irrigation area (\%) and land-use capability). Three were farm outputs (milksolids production per unit area, milksolids production per cow, and nitrogen loss from the soil profile). The remaining variables were: the number of cows milked; stocking rate; dairy system intensity (Types I to V); and the proportion of feed imported.

A statistics package - ClustOfvar (Chavent et al. 2012) from 'R Foundation' - was used to generate the cluster analysis. Some of the variables were categorical (non-numeric) and so Gower distances were calculated between the variables. Then, the Ward's linkage between groups of variables was used to minimise the sum of squared distances. Ward's linkage had a higher agglomerative coefficient (0.93537) than using single linkages, complete linkages or average linkages (Lance \& Williams 1967). A dendrogram of the results was used to identify five clusters of farms that could be used to represent all of the 126 Upper Manawatū River farms. The median information for the farms in each cluster was entered into Overseer 6.2.3 to create five representative farms for further analyses in Overseer.
Using a spreadsheet, a profit and loss account was created for each farm with consistent calculations and prices across all five farms. To avoid the management analyses becoming merely a 'mechanical' exercise three different farm consultants worked with two to three farms each.

\section{Farm practice mitigations}

The base-line information from the five representative farms were entered into Overseer 6.2.3 and the nitrogen leaching maxima calculated from the information contained in Table 1 (original trajectory) and the information in Table 2 (revised trajectory). Each baseline farm system was then modified to meet each of these trajectories by applying the management practices in Table 3, beginning with the operational changes and then the system changes. To keep the focus on the dairy industry, no land-use changes were included and any surplus conserved pasture that was not required within the dairy systems was sold off farm. Changes in pasture supply expected to result from changes in nitrogen practices were matched with changes in supplementary feed being imported into the farm system.

Farm shelter and animal housing were not included as a management option as the effect of adding these had already been addressed in a previous report (Parminter 2018). It was expected that milk production per cow would increase as milking cow numbers were

Table 3 The management practices incorporated into the representative farms so that they could operate within the nitrogen leaching maxima derived from Tables $1 \& 2$, in the order of their introduction

\section{Significance of Practices Management Practices}

Remove all nitrogen fertiliser applications from the effluent application area.

Remove winter applications of nitrogen (April to July inclusive).

Reduce annual nitrogen applications to $70 \mathrm{kgN} / \mathrm{ha}$ per year or less (population median).

Aggressively cull non-pregnant and poor performing cows by moving their cull-date one month earlier from April into March ( $17 \%$ of herd).

Replace high-protein imported feeds with low-protein (maize silage).

Remove all nitrogen applications except for a single application in spring, and reduce herd numbers to balance feed requirements.

The effluent treatment field was increased to reduce effluent applications to the equivalent of $100 \mathrm{kgN} /$ ha/yr.

Irrigation applications (on Cluster Farm \#4) were optimised to reduce drainage.

Graze off-farm (and out of catchment) (i) rising 2yr heifers and weaned calves (ii) dry cows retaining at least $0.5 \mathrm{cows} / \mathrm{ha}$ for winter grazing on the milking platform. And increase the amount of pasture conserved to maintain pasture production and reduce imported feed.

Shorten lactation length first to 10 May and reduce herd numbers and increase pasture conserved to maintain annual pasture production and reduce imported feed.

Shorten lactation length further to 30 April and reduce herd numbers and increase pasture conserved to maintain pasture production and reduce imported feed. 
reduced and whilst feed supply was maintained. Based on the catchment data, a response rate of $0.07 \mathrm{kgMS} /$ $\mathrm{kgDM}$ consumption was used (or $14.3 \mathrm{kgDM} / \mathrm{kgMS}$ ). A maximum herd production of $425 \mathrm{kgMS} / \mathrm{cow}$ was assumed, with an underlying annual improvement in production of $1.25 \%$ from genetic gain and herd selection (Parminter 2019).

\section{Financial analyses}

Each farm had an annual profit and loss account developed in a spreadsheet to match the farming systems described in Overseer and based on industry information held by the authors. The cost structure and financial assumptions of the profit and loss accounts used by the three farm consultants for all five farms were the same. In the accounts, fixed costs were: wages (a lumpy variable associated with cow numbers), repairs and maintenance, administration, insurance, and property rates. Land costs were: fertiliser and lime (excluding nitrogen); regrassing; weed \& pest control; and vehicle costs, as these varied with farm size. Livestock costs were: animal health; animal breeding; farm dairy; electricity; grazing; feed (including irrigation); crop, nitrogen; freight and cartage. These varied with livestock numbers or milk production. A milk price of $\$ 6.20 / \mathrm{kg}$ milksolids was assumed and a dividend of $\$ 0.3$ per share.

\section{Results}

\section{Representative farm attributes}

The cluster analysis of 126 dairy farms identified five clusters of farms where each farm was related to other farms within each cluster and dissimilar to the farms in the other clusters. The five clusters were selected based on their explanatory efficiency, and their results are shown in Table 4.

The annual rainfall for farms in the Upper Manawatū
River catchment is about $25 \%$ higher than the rest of the region (Table 4). Farm sizes in the catchment are a little smaller than the national average and dairy cow stocking rates are similar (LIC \& DairyNZ 2017). Milk production per hectare and per cow are lower than the average results for farms in the region and in New Zealand. The details of each of the five representative farms are:

- Representative Farm number 1 was on a predominantly Brown soil, with a slightly larger area than the median. Rainfall, milksolids production, and nutrient losses to water were typical for the catchment.

- Representative Farm number 2 was characterised by being mainly on recent soils with a higher stocking rate than many farms and higher milksolids production (per cow and per hectare). Nitrogen losses to water were similar to many farms in the catchment.

- Representative Farm number 3 was on Gley soils contributing towards lower nitrogen losses than is typical in the catchment. The stocking rate is lower than is typically found and although milksolids production per cow was typical, production per hectare was lower than the catchment median.

- Representative Farm number 4 was on Brown soils with a lower annual rainfall than the others. Over $50 \%$ of the milking platform was irrigated. This farm had a typical stocking rate and the highest milksolids production of all the farms (per cow and per hectare).

- Representative Farm number 5 represented the largest number of farms in the catchment. It was on Brown and Pallic soils with nitrogen losses that were typical for many farms in the catchment. It had a slightly lower stocking rate than is typical and although production per cow was similar to the median, production per hectare was lower.

Table 4 The five representative farms in the Upper Manawatū Catchment and some of the attributes used to describe them.

\begin{tabular}{|c|c|c|c|c|c|c|c|c|c|c|}
\hline $\begin{array}{l}\text { Representative } \\
\text { Farm } \\
\text { Identification * }\end{array}$ & $\begin{array}{l}\text { Number } \\
\text { of } \\
\text { farms }\end{array}$ & $\begin{array}{l}\text { Soil } \\
\text { Order }\end{array}$ & $\begin{array}{l}\text { Rainfall } \\
(\mathrm{mm})\end{array}$ & $\begin{array}{l}\text { Milking } \\
\text { Platform } \\
\text { Area (ha) }\end{array}$ & $\begin{array}{l}\text { Milking } \\
\text { Cows } \\
\text { (Peak) }\end{array}$ & $\begin{array}{l}\text { Production } \\
\text { per Cow } \\
\text { (kgMS/ } \\
\text { cow/yr) }\end{array}$ & $\begin{array}{l}\text { Production } \\
\text { per Hectare } \\
\text { (kgMS/ha/yr) }\end{array}$ & $\begin{array}{l}\text { Pasture } \\
\text { Consumption } \\
\text { (kgDM/ha/yr) }\end{array}$ & $\begin{array}{l}\text { Proportion } \\
\text { of Feed } \\
\text { Imported }\end{array}$ & $\begin{array}{l}\text { Base-line } \\
\text { Nitrogen } \\
\text { Loss } \\
\text { (kgN/ha/yr) }\end{array}$ \\
\hline 1 & 27 & Allophanic & 1,351 & 116 & 340 & 321 & 942 & 12,540 & 0.15 & 41 \\
\hline $2(\mathrm{RO})$ & 10 & Recent & 1,227 & 112 & 336 & 369 & 1,107 & 11,866 & 0.14 & 42 \\
\hline $3(\mathrm{RO})$ & 18 & Gley & 1,257 & 99 & 256 & 340 & 880 & 9,158 & 0.13 & 28 \\
\hline $4(\mathrm{RO})(\mathrm{IR})$ & 16 & Brown & 1,190 & 131 & 385 & 385 & 1,137 & 11,794 & 0.19 & 47 \\
\hline 5 & 55 & $\begin{array}{l}\text { Brown \& } \\
\text { Pallic }\end{array}$ & 1,351 & 108 & 270 & 336 & 840 & 11,007 & 0.13 & 39 \\
\hline $\begin{array}{l}\text { Median of all } \\
\text { farms in the } \\
\text { catchment }\end{array}$ & 126 & Brown & 1,298 & 111 & 309 & 340 & 902 & 10,092 & 0.16 & 39 \\
\hline
\end{tabular}

* $(\mathrm{RO})$ indicates farms with runoffs of 35-40 ha. (IR) indicates that the farm was irrigated. 
Original nitrogen leaching maxima in the One Plan

A summary of the comparison between the baseline representative farm-system outputs and the same outputs after year 20 of complying with the nitrogen leaching maxima in the One Plan (from Table 1) is provided in Table 5. In order to meet their nitrogen leaching maxima targets, it was assumed that all the farms have implemented all the operational management practices listed in Table 3. They have then added grazing offfarm, reducing herd numbers and shortening lactation length until nitrogen losses from the root zone have complied with Table 1 for year 20 .

Peak cow numbers indicate the productive potential of the farms but not their environmental impact. The scale of the stocking rate reductions achieved are better indicated through the reductions in relative stock units (RSU) rather than the changes in peak cow numbers. This is due to the RSU including the effect of grazing milking cows off-farm over winter.

All representative farm herds were assumed to increase milk production per cow similarly $(\mathrm{kgMS} / \mathrm{cow})$ as stocking rates were reduced. The final differences in farm milk production relate to their initial production differences. Costs of production were reduced as staff numbers reduced, maintenance fertiliser requirements were changed, and supplementary feed costs were reduced. The costs of grazing off-farm increased, especially for the farms without runoffs.

Farms $2 \& 3$ sold their surplus grass standing with no additional conservation costs. The other three farms were assumed to have conserved and sold their surplus grass as baleage.

In 2017-18, New Zealand dairy farms had median debt levels of $\$ 20-25 / \mathrm{kg}$ milksolids. The lower quartile of farms had debt of $\$ 10-15 / \mathrm{kg}$ milksolids and the upper quartile had debt of $\$ 35-45 / \mathrm{kg}$ milksolids (Matt Newman, DairyNZ, pers. comm.). A long-term interest rate of $7 \%$ was used to calculate that if the representative farms' debt was $\$ 22 / \mathrm{kg}$ milksolids, that their annual interest payments would be the following:

- Farm 1, \$1,379/ha

- Farm 2, \$1,208/ha

- Farm 3, \$932/ha

- Farm 4, \$1,334/ha

- Farm 5, \$1,226/ha

The farms in this study would need sufficient operating profits to clear their debt levels and in addition they needed enough operating profit to pay the farm owners and meet their taxation liabilities (Parminter 2018). If their debt levels are compared to the operating profits in Table 5 then the 55 farms (44\%) represented by Farm 5 would no longer be financially viable. The 27 farms (21\%) represented by Farm 1 would only be financially viable for the quarter of farms with the lowest debt. The 26 farms (21\%) represented by Farm 2 and Farm 4 would be financially viable except for the most heavily indebted quarter of farms, and the 18 farms (14\%) represented by Farm 3 are likely to be financially viable at almost all levels of industry debt.

The change in nitrogen losses between the representative farms in the base-line condition and year 20 is a reduction of over 55\% (Parminter et al. 2019).

\section{Revised nitrogen leaching maxima proposed for the One Plan}

When the process with the representative farms was repeated again, using the updated nitrogen leaching maxima in Table 2 , the results improve the viability of dairy farms in the catchment (shown in Table 6). Stocking rates needed to be reduced less with the revised nitrogen leaching maxima. Only Farms 1 \& 2 had some surplus pasture to sell. The other farms also reduced their stocking rates but were able to use the increased availability of pasture to increase milk production per cow up to a maximum of $425 \mathrm{~kg} \mathrm{MS} / \mathrm{cow}$. As a result of the greater efficiency with which pasture was used for dairy production, the profitability of the representative farms under the revised nitrogen leaching maxima

Table 5 The representative farm results for year twenty of the original nitrogen leaching maxima in the One Plan.

\begin{tabular}{|c|c|c|c|c|c|c|c|c|c|c|c|c|}
\hline \multirow[b]{2}{*}{$\begin{array}{l}\text { Representative } \\
\text { Farm } \\
\text { Identification* }\end{array}$} & \multicolumn{6}{|c|}{ Initial situation } & \multicolumn{6}{|c|}{ Year 20 of original nitrogen leaching maxima } \\
\hline & $\begin{array}{l}\text { Number } \\
\text { of } \\
\text { farms }\end{array}$ & $\begin{array}{l}\text { Peak } \\
\text { Cows } \\
\text { (cows/ } \\
\text { ha) }\end{array}$ & $\begin{array}{l}\text { Stocking } \\
\text { Rate } \\
\text { (RSU/ha) }\end{array}$ & $\begin{array}{l}\text { Production } \\
\text { (kgMS/ha) }\end{array}$ & $\begin{array}{l}\text { Operating } \\
\text { Profit } \\
\text { (\$/ha) }\end{array}$ & $\begin{array}{l}\text { Farm } \\
\text { Working } \\
\text { Expenses } \\
\text { (\$/kgMS) }\end{array}$ & $\begin{array}{l}\text { Peak } \\
\text { Cows } \\
\text { (cows/ } \\
\text { ha) }\end{array}$ & $\begin{array}{l}\text { Stocking } \\
\text { Rate } \\
\text { (RSU/ha) }\end{array}$ & $\begin{array}{l}\text { Production } \\
\text { (kgMS/ha) }\end{array}$ & $\begin{array}{l}\text { Operating } \\
\text { Profit } \\
\text { (\$/ha) }\end{array}$ & $\begin{array}{l}\text { Farm } \\
\text { Working } \\
\text { Expenses } \\
\text { (\$/kgMS) }\end{array}$ & $\begin{array}{l}\text { Nitrogen } \\
\text { Loss } \\
\text { (kgN/ha/ } \\
\text { yr) }\end{array}$ \\
\hline 1 & 27 & 2.9 & 24.3 & 942 & 2,020 & 4.79 & 1.3 & 12.0 & 478 & 1,188 & 6.37 & 16 \\
\hline $2(\mathrm{RO})$ & 10 & 3.0 & 22.7 & 1,107 & 3,367 & 3.83 & 1.3 & 10.9 & 569 & 1,889 & 4.90 & 18 \\
\hline $3(\mathrm{RO})$ & 18 & 2.6 & 18.5 & 880 & 1,880 & 4.78 & 1.8 & 13.6 & 752 & 2,118 & 4.52 & 17 \\
\hline $4(\mathrm{RO})(\mathrm{IR})$ & 16 & 2.9 & 25.3 & 1,137 & 3,161 & 4.09 & 2.3 & 17.4 & 973 & 2,092 & 4.79 & 18 \\
\hline 5 & 55 & 2.5 & 21.5 & 840 & 1,618 & 5.00 & 0.9 & 9.4 & 394 & 401 & 7.67 & 16 \\
\hline
\end{tabular}

* $(\mathrm{RO})$ indicates farms with runoffs of 35-40 ha. (IR) indicates that the farm was irrigated. 
was high enough for them to generally remain viable. However, the most heavily indebted quarter of the 55 farms represented by Farm 5 may still not be financially viable if these changes were to be introduced.

The change in nitrogen losses between the representative farms in the baseline condition and year 20 is a reduction of over 37\% (Parminter et al. 2019).

\section{Discussion and Conclusions}

The results of this study highlight the difficulties created when statutory policies are not able to adapt at the same rate as scientific advances in the technologies that underpin them. In this example, a technology suited to 2007 was no longer suitable in 2018 and the difference has significant consequences for the Tararua District economy (NZIER 2018). The situation can be addressed as shown in this study by updating Rule 14.1 and Table 14.2 in the One Plan.

Recent interest rates for dairy farmers in New Zealand have been trending downwards; however, the draft
Reserve Bank policy for Commercial Banks to retain more capital is expected to be passed onto borrowers through increases in their interest rates. Increases in interest for dairy farmers of 0.5 to 1.5 percentage units have been suggested (Matthew Newman pers. comm.).

Dairy farmers are not able to pass on increases in production costs incurred within New Zealand to overseas consumers of their products. The additional costs of achieving compliance described in this paper are likely to reduce their resilience and robustness to milk price volatility (Neal \& Roche 2019). Stocking rates matched to feed supply are critical to efficient pasture-based farming systems (Neal \& Roche 2019; Muller 2017). In situations where stocking rates are lower than would be optimal, dairy farmers have to closely monitor both pasture cover and pasture quality and they may need to top their paddocks, cutting pasture to waste (McDonald et al. 2001).

It is possible that further analyses could explore changes in farmers' capability by optimising the farm

Table 6 The representative farm results for year twenty of the revised nitrogen leaching maxima.

\begin{tabular}{|c|c|c|c|c|c|c|c|}
\hline \multirow{2}{*}{\multicolumn{2}{|c|}{$\begin{array}{l}\text { Initial Farm } \\
\text { Representative } \\
\text { Farm } \\
\text { Identification * }\end{array}$}} & \multicolumn{6}{|c|}{ Year 20 of nitrogen leaching maxima } \\
\hline & & $\begin{array}{l}\text { Peak } \\
\text { Cows } \\
\text { (cows/ha) }\end{array}$ & $\begin{array}{l}\text { Stocking } \\
\text { Rate } \\
\text { (RSU/ha) }\end{array}$ & $\begin{array}{l}\text { Production } \\
\text { (kgMS/ha) }\end{array}$ & $\begin{array}{l}\text { Operating } \\
\text { Profit (\$/ha) }\end{array}$ & $\begin{array}{l}\text { Farm } \\
\text { Working } \\
\text { Expenses } \\
\text { (\$/kgMS) }\end{array}$ & $\begin{array}{l}\text { Nitrogen } \\
\text { Loss } \\
\text { (kgN/ha/ } \\
\text { yr) }\end{array}$ \\
\hline \multirow[t]{4}{*}{1} & Original nitrogen leaching maxima & 1.3 & 12.0 & 478 & 1,188 & 6.37 & 16 \\
\hline & Percentage difference from baseline & $-55 \%$ & $-51 \%$ & $-49 \%$ & $-41 \%$ & $25 \%$ & $-61 \%$ \\
\hline & Revised nitrogen leaching maxima & 2.0 & 18.1 & 810 & 2,052 & 4.76 & 24 \\
\hline & Percentage difference from baseline & $-31 \%$ & $-26 \%$ & $-14 \%$ & $2 \%$ & $-1 \%$ & $-41 \%$ \\
\hline \multirow[t]{4}{*}{$2(\mathrm{RO})$} & Original nitrogen leaching maxima & 1.3 & 10.9 & 569 & 1,889 & 4.9 & 18 \\
\hline & Percentage difference from baseline & $-57 \%$ & $-52 \%$ & $-49 \%$ & $-44 \%$ & $3 \%$ & $-57 \%$ \\
\hline & Revised nitrogen leaching maxima & 2.3 & 19.3 & 987 & 3,425 & 3.58 & 28 \\
\hline & Percentage difference from baseline & $23 \%$ & $-15 \%$ & $-11 \%$ & $2 \%$ & $-7 \%$ & $-33 \%$ \\
\hline \multirow[t]{4}{*}{$3(\mathrm{RO})$} & Original nitrogen leaching maxima & 1.8 & 13.6 & 752 & 2,118 & 4.52 & 17 \\
\hline & Percentage difference from baseline & $-31 \%$ & $-26 \%$ & $-15 \%$ & $13 \%$ & $-5 \%$ & $-39 \%$ \\
\hline & Revised nitrogen leaching maxima & 2.4 & 18.8 & 1008 & 2,483 & 4.33 & 28 \\
\hline & Percentage difference from baseline & $-8 \%$ & $2 \%$ & $15 \%$ & $32 \%$ & $-9 \%$ & $0 \%$ \\
\hline \multirow[t]{4}{*}{$4(\mathrm{RO})(\mathrm{IR})$} & Original nitrogen leaching maxima & 2.3 & 17.4 & 973 & 2092 & 4.79 & 18 \\
\hline & Percentage difference from baseline & $-21 \%$ & $-31 \%$ & $-14 \%$ & $-34 \%$ & $17 \%$ & $-62 \%$ \\
\hline & Revised nitrogen leaching maxima & 2.7 & 20.0 & 1081 & 1,924 & 5.06 & 22 \\
\hline & Percentage difference from baseline & $-7 \%$ & $-21 \%$ & $-5 \%$ & $-39 \%$ & $24 \%$ & $-53 \%$ \\
\hline \multirow[t]{4}{*}{5} & Original nitrogen leaching maxima & 0.9 & 9.4 & 394 & 401 & 7.67 & 16 \\
\hline & Percentage difference from baseline & $-64 \%$ & $-56 \%$ & $-53 \%$ & $-75 \%$ & $53 \%$ & $-59 \%$ \\
\hline & Revised nitrogen leaching maxima & 2.1 & 18.5 & 793 & 1,271 & 5.33 & 24 \\
\hline & Percentage difference from baseline & $-16 \%$ & $-14 \%$ & $-6 \%$ & $-21 \%$ & $1 \%$ & $-38 \%$ \\
\hline
\end{tabular}

* $(\mathrm{RO})$ indicates farms with runoffs of 35-40 ha. (IR) indicates that the farm was irrigated. 
systems before they are compared. That was not done in this study. It is also possible to use these results and compare them with results of other industries, e.g. beef production or arable farming. Further information about some possible land-use comparisons can be found in other Regional Council reports (Parminter 2018; NZIER 2018; Ridler 2017).

The results of this study further highlight the variability of impacts of regional policies on farming industries. That variability has only been made visible in this study because a cluster analysis was used to assist with the identification of the representative farms for the whole industry in one area. The range in farm systems provided by the cluster analysis enabled the impact analysis results of this study to be widely applicable across the whole catchment.

With careful management of farm systems, over the next twenty years, nitrogen loss reductions of $37-55 \%$ are possible from dairying in the catchment depending on the table of nitrogen leaching maxima applied. Not all of this reduction will reach the receiving waterway as before it reaches the waterway some of it will be attenuated through intervening soil conditions. The results of the study indicate that the choice of nitrogen leaching maxima can have a big influence on the financial viability of some dairy farms in the Region and that this also needs to be taken into account when selecting the table to be included in the One Plan.

\section{ACKNOWLEDGEMENTS}

Our thanks to work colleagues and farmers for discussions in preparation for this paper. The research was funded by Manawatū-Wanganui Regional Council; however, the contents of this paper do not constitute or imply the policy direction of the Council either now or in the future. Matthew Newman at DairyNZ provided some of the information used in this paper and his advice was also appreciated.

\section{REFERENCES}

Chavent M, Kuentz-Simonetv, Liquet B, Saracco J. 2012. ClustOfVar: An R Package for the clustering of variables. Journal of Statistical Software $50 \mathrm{https}$ :// doi.org/10.18637/jss.v050.i13

Hanly J, Hedley M, Horne D. 2018. Sensitivity of values in Table 14.2 of the 'One Plan' to a change in the version of OVERSEER $\AA$. A Fertilizer and Lime Research Centre client report for ManawatūWanganui Regional Council. Accessed July 2019 http://www.horizons.govt.nz/HRC/media/Media/ One\%20Plan\%20Documents/FLRC-RevisedTable-14-2-Summary-Report-(Part-A-and-B)January-2018.pdf?ext=.pdf

Lance GN, Williams WT. 1967. A general theory of classificatory sorting strategies: 1. Hierarchical systems. The Computer Journal 9(4): 373-380.

Livestock Improvement Corporation Ltd and DairyNZ Ltd. 2017. New Zealand Dairy Statistics 2016-17. LIC Ltd, Newstead, New Zealand.

Manawatū-Wanganui Regional Council. 2014. One Plan: The Consolidated Regional Policy Statement, Regional Plan and Regional Coastal Plan for the Manawatū-Wanganui Region. Horizons Regional Council, Palmerston North, New Zealand.

Macdonald KA, Penno JW, Nicholas PK, Lile JA, Coulter M, Lancaster JAS. 2001. Farm systems - Impact of stocking rate on dairy farm efficiency. Proceedings of the New Zealand Grassland Association 63: 223-227.

Muller C. 2017. Modelling dairy farm systems: processes, predicaments and possibilities. In: Science and policy: nutrient management challenges for the next generation. In: Currie LD \& Hedley MJ Eds. Occasional Report No. 30. Fertilizer and Lime Research Centre, Massey University, Palmerston North, New Zealand.

Neal M, Roche J. 2019. Profitable and resilient pasturebased dairy farm businesses in New Zealand. Animal Production Science: https://doi.org/10.1071/ AN18572.

New Zealand Government. 1991. Resource Management Act, reprint. 2017. New Zealand Government, Wellington, New Zealand.

NZIER. 2018. The macroeconomic impacts of the One Plan's intensive land use provisions. A client report for Manawatū-Wanganui Regional Council. Accessed July 2019 https://www.horizons.govt.nz/ HRC/media/Media/One\%20Plan\%20Documents/ Horizons-One-Plan-LU-EIA-final-report-24July-2018_.pdf?ext=.pdf .

Parminter TG. 2018. An impact assessment of One Plan policies and rules on farming systems in the Tararua District and the Manawatu-Wanganui Region. KapAg Ltd client report for Manawatū-Wanganui Regional Council. Accessed July 2019 from https:// www.horizons.govt.nz/HRC/media/Media/One $\% 20$ Plan\%20Documents/Parminter-Impact-AssessmentReport-January-2018.pdf?ext=.pdf.

Parminter TG, Ridsdale S, Bryant S. 2019. The possible impact of having regional nitrogen caps on the milk production and financial viability of dairy farms in the Upper Manawatū River catchment of the Tararua District. In: Nutrient loss mitigations for compliance in agriculture. In: Currie LD \& Hedley MJ Eds. Occasional Report No. 32. Fertilizer and Lime Research Centre, Massey University, Palmerston North, New Zealand. Accessed July 2019 from http:// flrc.massey.ac.nz/publications.html.

Ridler B. 2017. The feasibility of nutrient leaching reductions (N leaching) within the constraints of 
minimum impact on the profitability and production of three dairy farms in the Horizons Region. A client report for Manawatū-Wanganui Regional Council. Accessed July 2019 https://www.horizons.govt.nz/ HRC/media/Media/One\%20Plan\%20Documents/
Ridler-Representative-Farm-Report-January-2018. pdf?ext=.pdf.

Rokach L, Maimon O. 2005. Clustering methods: Data mining and knowledge discovery handbook. Springer US. 